\title{
Production of biodiesel by enzymatic catalysis from the castor oil: an analytical chemical study
}

\begin{abstract}
The study aimed at the development of a method for obtaining biodiesel by transesterification by via methylic from castor oil using biocatalysts. Seven varieties of lipase (PPL, Candida rugosa, OS cepacea, OS cepacea immobilized on diatomaceous earth, Novozyme 435, Lipozyme and Lipozyme RM) and seven enzymatic sources from a vegetable origin (latex of the species Ficus benjamina, Manihot glaziovii Muell. Arg., Calotropis procera, Jatropha curcas L., Ficus pumila, Euphorbia tirucalli L.) were tested. Enzymatic sources of plant origin were submitted, initially, the hydrolytic activity tests to evaluate their potential as biocatalysts and, from the results obtained, two samples were selected for the experiments further synthesis of biodiesel. Validation of the method of production of biodiesel evaluated linearity, reproducibility (precision), recovery (accuracy) and the limits of detection and quantification. Among the sources of enzymes used in the synthesis of biodiesel presented the best result was the commercial enzyme Novozym 435 with $55.33 \%$ conversion yield of biodiesel in initial tests. Were conducted new tests for optimization of reactional parameters co-solvent, alcohol: oil ratio, amount of enzyme and solvent for recovery of the enzyme, which enabled a maximum yield of biodiesel to $98.84 \%$.
\end{abstract}

Keywords: biodiesel, lipase, enzyme, castor oil
Volume 9 Issue 3 - 2020

\author{
Edilane de Sousa Gomes,' Telma Leda de \\ Lemos,' Marcos Carlos de Mattos,' Eneas \\ Gomes Filho, ${ }^{2}$ Caio Victor Pereira Pascoal, ${ }^{3}$ \\ Joao Carlos da Costa Assuncao, ${ }^{4}$ Francisco \\ Jose Queiroz Monte' \\ 'Department of Chemistry, Federal University of Ceara/Ceara, \\ Brazil \\ ${ }^{2}$ Department of Biochemistry, Federal University of Ceara/ \\ Ceara, Brazil \\ ${ }^{3}$ Department of Metallurgical and Materials Engineering, Federal \\ University of Ceara/Ceara, Brazil \\ ${ }^{4}$ Department of Chemistry and Environment, Federal Institute \\ of Ceara-campus Maracanau/Ceara, Brazil
}

\begin{abstract}
Correspondence: Joao Carlos da Costa Assuncao, Federal Institute of Ceara-campus Maracanau, Avenue Contorno NorteIndustrial District, Maracanau, Ceara, Brazil, Tel +558538786346, Email joaocarlos@ifce.edu.br
\end{abstract}

Received: December 26, 2019 | Published: August 07, 2020

\section{Introduction}

In the last decades the search for alternative fuels is gaining prominence on the world stage motivated, above all, for economic and environmental issues caused by the use of fossil fuels. In this context arose biofuels, renewable source of energy derived from biomass and releasing into the atmosphere quantities of pollutants significantly smaller than fossil fuels. ${ }^{1}$ Among biofuels, biodiesel consists of a derivative obtained from vegetable oils and which represents an alternative in relation to the use of petroleum-derived diesel. Biodiesel is known as a carbon neutral fuel because the carbon present in the exhaust was originally fixed from the atmosphere. ${ }^{2}$ Compared to other types of fuel, biodiesel has the major advantages of being biodegradable and producing significantly lower levels of noxious emissions..$^{3-4}$ The use of this biofuel was reported in the 19th century, when Rudolf Diesel, inventor of the diesel engine, used peanut oil as fuel engine power in his experiments. But, at that time, the low cost and high availability of oil, associated with the technical problems resulting from the use of fresh vegetable oil directly on the engines, decisively influenced the choice of oil as feedstock for fuel production. ${ }^{5-7}$ The route commonly used for obtaining biodiesel is the transesterification of triacylglycerols (TAG) found in fats and oils. The transesterification reduces the viscosity of oils and fats by improving their fuel feature. In this reaction it is customary to use a short chain alcohol (methanol, ethanol, propanol) and a catalyst to speed up the reaction. The most commonly used catalysts are strong bases $(\mathrm{NaOH}$, $\mathrm{KOH}$ ), strong acids and enzymes. The latter has drawn enough attention due to some disadvantages of acid catalysts (slow reaction) and basic (higher viscosity, formation of soap and gel that inhibits separation of glycerol). The principals advantages of enzymatic transesterification with respect to the acid and alkaline process, are: the possibility to carry out the conversion at low temperature conditions; lipases also catalyze esterification of free fatty acids; ${ }^{8,9}$ small quantities of water in the reacting mixture are admitted and, in some cases, necessary; ${ }^{10}$ the yield in esters is relatively higher; it is not necessary to purify the produced esters.

The reuse of lipases and the recovery of their stability, both thermal and mechanical, are the most significant issues for making the enzymatic process, whose costs are still too high, more competitive for biodiesel production. Immobilized lipases permit to achieve this goal. However, they can be maximally exploited only if operating conditions are optimized; this task requires knowledge of reaction kinetics and, in general, predictions of process performance.

The castor is the fruit of an oleaginous plant Euphorbia family, scientifically called Ricinus communis. Due to ease of adaptation to the most varied weather conditions, this plant is found and cultivated in various regions of the world (EMBRAPA, 2012). ${ }^{11}$ The chemical composition of the Castor oil is rather peculiar. Unlike most vegetable oils, is composed almost exclusively by a glicerídeo derived from a single fatty acid ricinoleic acid. This fatty acid is unique in that it features a hydroxyl in their chemical structure, that gives the larger oil solubility in polar solvents, allowing their use in various reactional processes. ${ }^{11}$ As an example, can be cited obtaining high added value fatty acids such as linoleic acid. ${ }^{12}$ Moreover, the presence of hydroxyl provides greater viscosity and oil due to these characteristics, the Castor oil is used as raw material for the production of automobile lubricants and additives. ${ }^{12,13}$ The use of castor oil for energy purposes presents a series of advantages. From a technical point of view, oil presents high capacity to withstand high temperatures maintaining its original viscosity, low waste production during his burns and represents a renewable energy source. As the production of castor seeds present high oil levels thereby ensuring a respectable productivity per hectare is planted..$^{12,13}$ Despite the advantages mentioned the biodiesel from castor oil faces challenges. 
One of them is raised by resolution number 7 of the National Petroleum Agency (ANP), Brazilian regulator. According to this resolution due to high oil viscosity, it would be infeasible to produce biodiesel B100 (pure biodiesel) from the castor oil plant. However, one must take into consideration that the current production of biodiesel in Brazil is still in the order of B3 (3\% of biodiesel added to petroleum diesel). In addition, this myth has been faced by researchers who study the feasibility of this oil for energy purposes. Some experts emphasize that biodiesel from castor oil supports with good viscosity until the production of the B40. Also, it is necessary to report the opinion of these experts who highlight that there is no oil that, in isolation, is perfect for biodiesel production.

\section{Materials and methods}

\section{Enzymes}

Candida antarctica lipase B (Novozyme 453 or CAL-B), Aspergillus oryzae (Lipozyme RM), Amano lipase OS of Burkholderia cepacia, Amano lipase OS of Burkholderia cepacia immobilized on the of diatomaceous earth, Lipozyme, lipase of Candida rugosa and lipase from the pancreas of pigs (PPL) was kindly provided by Novozymes Brazil. The latex of the species Ficus benjamina, Manihot glaziovii Muell. Arg., Calotropis procera, Jatropha curcas L., Ficus pumila, Euphorbia tirucalli L. were collected in Quixada, Ceara, Brazil.

\section{Reagents}

The fatty acids, palmitic, estearic, linoleic, oleic and ricinoleic, and ethyl oleate were obtained from Sigma Brazil. Olive oil was obtained from a commercial source. The refined castor oil was provided by OLVEQ (vegetable oils of Quixada), company that works with improvement of this product in the city of Quixada. All other chemicals were of analytical reagent grade.

\section{Synthesis of the chromatographic patterns}

$2.0 \mathrm{~g}$ of fatty acid were dissolved in $20 \mathrm{~mL}$ of methanol, mixed 1.0 $\mathrm{mL}$ of concentrated hydrochloric acid $(\mathrm{HCl})$ and stirred magnetically under reflux $\left(60^{\circ} \mathrm{C}\right)$ for $1 \mathrm{~h}$. After the reaction time, the material was concentrated in rotary evaporator. Subsequently, the material was purified by column chromatography, using silica gel and park phase mobile phase of hexane/ethyl acetate in proportions of 0 to 100 to ethyl acetate. The fractions obtained were subjected to thinlayer chromatography to assess the purity of the fractions. To prove the identities of esters obtained, the samples were analyzed by gas chromatography coupled to mass spectrometry (GC-MS) equipped with OV-5 capillary column $(30 \mathrm{~m} \times 0.25 \mathrm{~mm} \times 0.25 \mu \mathrm{m})$ and nuclear magnetic resonance $\left({ }^{1} \mathrm{H}\right.$ and $\left.{ }^{13} \mathrm{C} \mathrm{NMR}\right)$.

\section{Calibration curve}

Standard solutions of methyl esters were prepared in concentration ranges from 50 to $1500 \mu \mathrm{g} / \mathrm{mL}$. Ethyl oleate was used as internal standard. An aliquot of $5 \mu \mathrm{L}$ of each standard solution was mixing a $100 \mu \mathrm{L}$ of internal standard solution $(500 \mathrm{~g} / \mathrm{mL}), 1 \mu \mathrm{L}$ of this mixture injected into the GC-MS. Calibration curves were constructed through linear regression, plotting the peak area of analyte/internal standard peak area versus concentration of the analyte.

\section{Analytical method validation}

The analytical method was validated for all component methyl ester biodiesel from castor oil. The parameters evaluated were linearity, accuracy, precision, limit of detection (LD) and limit of quantification (LQ).

\section{Determination of hydrolytic activity}

Determination of hydrolytic activity was conducted using methodology adapted from Moreira (2007). ${ }^{14}$ An emulsion was prepared with olive oil $(5 \% \mathrm{w} / \mathrm{v})$, gum arabic $(10 \% \mathrm{w} / \mathrm{v})$ and $100 \mathrm{~mL}$ of phosphate buffer solution $\mathrm{pH}$ 7.0.20 mL of emulsion (substrate) and $0.5 \mathrm{~g}$ of biocatalyst (latex or lentil seeds) were sealed in $125 \mathrm{~mL}$ bottles and subjected to agitation for 30 minutes at $37^{\circ} \mathrm{C}$ and $150 \mathrm{rpm}$. After the reaction time, were added $20 \mathrm{~mL}$ of a solution of acetone/ethanol (1:1). Then added a few drops of phenolphthalein and samples were titrated with a solution of $\mathrm{NaOH} 0.05 \mathrm{M}$. The hydrolytic activity was determined using formula expressed by Equation 1. The experiments were conducted in triplicate and, in parallel, tests were carried out in white with $0.5 \mathrm{~g}$ distilled water, replacing the biocatalyst.

$$
A_{H}=\left(V_{a} \cdot V_{b}\right) \cdot M \cdot 1000 / t . m
$$

where: $A_{H}=$ hydrolytic activity $(\mathrm{U} / \mathrm{g}) ; \mathrm{V}_{\mathrm{a}}=$ volume of titrant used for sample $(\mathrm{mL}) ; \mathrm{V}_{\mathrm{b}}=$ volume of titrant used for white $(\mathrm{mL}) ; \mathrm{M}=$ molar concentration of the standard solution of $\mathrm{NaOH}$; $\mathrm{t}=$ reaction time ( $\mathrm{min}) ; \mathrm{m}=$ mass of the sample used in the reaction $(\mathrm{g})$.

\section{Enzymatic transesterification reaction}

$50 \mathrm{mg}$ of biocatalyst were added to $200 \mathrm{mg}$ of castor oil, previously dissolved in $2.0 \mathrm{~mL}$ of methanol. The reactional system was shaken on orbital shaker $(150 \mathrm{rpm})$, at room temperature $\left(\sim 28^{\circ} \mathrm{C}\right)$. At the end of the reaction, the enzyme system was separated by filtration and the filtrate was centrifuged (12000 rpm, 10 minutes) and an aliquot $(5 \mu \mathrm{L})$ upper stage was mixed with $100 \mu \mathrm{L}$ of a solution of ethyl oleate 500 $\mu \mathrm{g} / \mathrm{mL}$ (internal standard) and $1 \mu \mathrm{L}$ of this mixture injected into the GC-MS. The methyl esters were quantified using calibration curves obtained from the same standards solutions, injected in the same way as samples.

\section{Optimization of the enzymatic transesterification reactions}

The biocatalyst that showed better performance in transesterification reaction was selected for new experiments, being certain some ideal conditions for the reaction. The effects of co-solvent, molar ration alcohol/oil, enzyme amount, $\mathrm{pH}$ and solvent for recovery of biocatalyst were evaluated. In all experiments the mixtures analyzed reactions according to the methodology described above.

\section{Co-solvent and addition of methanol in stages}

The following co-solvents were evaluated: petroleum ether, acetone, dimethyl sulfoxide (DMSO), dioxane, ethyl acetate, ethanol and hexane. In conical flask of $50 \mathrm{~mL}$ were added $2.0 \mathrm{~mL}$ of cosolvent, $200 \mathrm{mg}$ of castor oil, $50 \mathrm{mg}$ of biocatalyst (Novozym 435) and $0.5 \mathrm{~mL}$ of methanol. The system was sealed and submitted to agitation through an orbital shaker $(150 \mathrm{rpm})$, at room temperature ( $28^{\circ} \mathrm{C}$ ). $0.5 \mathrm{~mL}$ of methanol were added at intervals of 60 minutes up to a total volume of $2.0 \mathrm{~mL}$ of alcohol in the reaction system.

\section{Molar ration alcohol/oil}

To determine the best molar ration alcohol/oil five different experiments were performed, with the reasons: $3: 1,8: 1,10: 1,100: 1$ 
and 240:1. In conical flask of $50 \mathrm{~mL}$ were added $2.0 \mathrm{~mL}$ of hexane, $200 \mathrm{mg}$ of castor oil, $50 \mathrm{mg}$ of biocatalyst (Novozyme 435) and the amount of methanol calculated for each molar ration. The system was sealed and submitted to agitation through an orbital shaker $(150 \mathrm{rpm})$ at room temperature $\left(\sim 28^{\circ} \mathrm{c}\right)$. After $1 \mathrm{~h}$ of reaction were added 467 $\mu \mathrm{L}$ and $500 \mu \mathrm{L}$ of methanol reactional systems that corresponded, respectively, the reasons of molars 100:1 and 240:1. For the reaction system with 240:1 molar ratio, were made two more additions to each $1 \mathrm{~h}$ of $500 \mu \mathrm{L}$ each.

\section{Amount of enzyme}

To assess the effect of the variation of the amount of enzyme in relation to the amount of oil, five different experiments were performed, in proportions of enzyme/oil $5 \%, 10 \%, 15 \%, 25 \%$ and $30 \%$. In conical flask of $50 \mathrm{~mL}$ were added $2.0 \mathrm{~mL}$ of hexane, $200 \mathrm{mg}$ of castor oil, the mass of biocatalyst (Novozym 435) needed for each ratio and $0.5 \mathrm{~mL}$ of methanol.

\section{$\mathrm{pH}$}

To evaluate the optimal $\mathrm{pH}$ of the enzyme reactional systems were prepared in sodium phosphate buffer $\mathrm{pH}$ 5.2, 6.1, 7.2 and 7.8. For each reaction have been added $2 \mathrm{~mL}$ of buffer and $0.05 \mathrm{~g}$ of the enzyme.

\section{Solvent for recovery of biocatalyst}

The enzymes used in previous experiments were treated (washed) with three different solvents, hexane, acetone and ethanol. After all the solvent evaporated the enzymes were reused in new reactions of transesterification using $50 \mathrm{mg}$ of enzyme, $2.0 \mathrm{~mL}$ of hexane, $200 \mathrm{mg}$ of oil and $2.0 \mathrm{~mL}$ of methanol (added in stages) as previously adopted methodology.

\section{Statistical analysis}

The results were expressed in terms of mean \pm standard deviation. The comparisons between the groups were analyzed using one-way analysis of variance (ANOVA), followed by Turkey's test using the Statistica version 10 software. A p-value of less than 0.05 was considered statistically significant.

\section{Results}

\section{Analytical method validation}

The first step of the study consisted in assessing the performance of the analytical methodology for the validation of chromatographic method used in the analysis of biodiesel. The parameters evaluated were linearity, accuracy, precision, limit of detection (LD) and limit of quantification (LQ). Were identified in the biodiesel five methyl esters (linoleato, palmitate, oleate, stearate and ricinoleate) being the predominant components ricinoleate, with content above $90 \%$.

\section{Linearity}

The linearity of the method was evaluated through linear regression coefficient (R). A value of R near the unit (1.0000) indicates that the response of the detector is proportional to the concentration of ester. The results of this study are shown in Table 1. All experiments were performed in triplicate.

\section{Accuracy}

The accuracy of the method was evaluated by determining the recovery, using multi-element solutions of the esters at concentrations of 100 and $200 \mu \mathrm{g} / \mathrm{mL}$. The amount recovered, the percentage recovery and standard deviation of the measurements can be verified in Table 2.

Table I Equations of the calibration curve and linearity coefficients for the castor oil methyl esters

\begin{tabular}{lll}
\hline Methyl ester & Equation & R \\
\hline Palmitate & $y=0.0002 x-0.0062$ & 0.9972 \\
Linoleate & $y=0.00003 x+0.0019$ & 0.9989 \\
Oleate & $y=0.00009 x-0.0038$ & 0.9993 \\
Estearate & $y=0.0002 x-0.0109$ & 0.9987 \\
ricinoleate & $y=0.00007 x-0.0056$ & 0.9958 \\
\hline
\end{tabular}

Table 2 Results of recovery of methyl esters standards

\begin{tabular}{|c|c|c|c|c|}
\hline \multirow[b]{2}{*}{$\begin{array}{l}\text { Methyl } \\
\text { ester }\end{array}$} & \multicolumn{2}{|l|}{$100 \mu \mathrm{g} / \mathrm{mL}$} & \multicolumn{2}{|l|}{$200 \mu \mathrm{g} / \mathrm{mL}$} \\
\hline & $\begin{array}{l}\text { Amount } \\
\text { recovered } \\
(\mu g / m L)\end{array}$ & $\begin{array}{l}\text { \%Recovery } \\
( \pm S D) \\
(n=3)^{*}\end{array}$ & $\begin{array}{l}\text { Amount } \\
\text { recovered } \\
(\mu g / m L)\end{array}$ & $\begin{array}{l}\text { \%Recovery } \\
( \pm S D)(n=3)\end{array}$ \\
\hline Palmitate & 95.02 & $95.02 \pm 5.99$ & 171.76 & $85.88 \pm 6.27$ \\
\hline Linoleate & 83.74 & $83.74 \pm 2.05$ & 15328 & $76.65 \pm 5.42$ \\
\hline Oleate & 122.19 & $122.19 \pm 3.08$ & 202.24 & $101.12 \pm 7.30$ \\
\hline Estearate & 108.95 & $108.95 \pm 3.98$ & 181.01 & $90.51 \pm 4.57$ \\
\hline Ricinoleate & 123.35 & $123.35 \pm 3.02$ & 166.77 & $83.39 \pm 1.91$ \\
\hline
\end{tabular}

$*_{\mathrm{n}}$, number of repetitions; SD, standard deviation

\section{Precision}

The accuracy of the method was evaluated by reproducibility, as measured by the coefficient of variance $(\mathrm{CV})$ obtained in tests on different days. Solutions $100 \mu \mathrm{g} / \mathrm{mL}$ were injected into, quadruplicate, and $\mathrm{CV}$ were calculated. The standard deviations and coefficients of variances can be checked in Table 3 .

Table 3 Results of reproducibility using solutions $100 \mu \mathrm{g} / \mathrm{mL}$ of methyl esters

\begin{tabular}{llll}
\hline Methyl ester & $\begin{array}{l}\text { Calculated } \\
\text { concentration }(\mu \mathrm{g} / \mathrm{mL})\end{array}$ & SD $(\mathbf{n}=4) *$ & $\mathbf{C V}(\%)$ \\
\hline Palmitate & 98.02 & 3.99 & 4.07 \\
Linoleate & 93.23 & 2.02 & 2.17 \\
Oleate & 120.02 & 3.01 & 2.51 \\
Estearate & 106.85 & 3.68 & 3.44 \\
Ricinoleate & 121.35 & 3.12 & 2.57 \\
\hline
\end{tabular}

$*_{n}$, number of repetitions.

\section{Limits of detection (LD) and quantification (LQ)}

The limits of detection (LD) and quantification (LQ) were calculated from the standard deviation of the intercept with the y $(\sigma)$ axis and the slope $(\mathrm{S})$ of three calibration curves, calculated as: $\mathrm{LD}=$ $3 \mathrm{x} \sigma / \mathrm{S}$ and $\mathrm{LQ}=10 \mathrm{x} \sigma / \mathrm{S} .{ }^{15}$ The results of $\mathrm{LD}$ and $\mathrm{LQ}$ for the esters are shown in Table 4.

\section{Determination of hydrolytic activity}

Some studies in the literature report the presence of lipases in various plant sources such as latex and oil seeds. ${ }^{16-18}$ For this reason, six latex samples of plant species Ficus benjamina, Manihot glaziovii 
Muell. Arg., Calotropis procera, Jatropha curcas L., Ficus pumila, Euphorbia tirucalli L., Ficus benjamina e Manihot glaziovii Muell. Arg., Calotropis procera e Jatropha curcas L. were selected for determination of hydrolytic activities. The enzyme activity was determined by the method of hydrolysis of olive oil, according to the adopted methodology of Moreira (2007). ${ }^{14}$ The method is based on the detection of fatty acids released by the action of enzymes on the glycerides of olive oil as a function of time. Quantification of free fatty acids was performed by titration with standard alkaline solution, being the hydrolytic activity determined by equation 1 . The activity was defined as the amount of enzyme which liberates $1 \mu \mathrm{mol}$ of fatty acid per minute of reaction. The results of these experiments were expressed in $\mu \mathrm{mol} / \mathrm{g} . \mathrm{min}(\mathrm{Ug})$ and are shown in Table 5.

Table 4 Limits of detection (LD) and quantification (LQ) for patterns of methyl esters of castor oil

\begin{tabular}{lll}
\hline Methyl ester & LD $(\boldsymbol{\mu g} / \mathbf{m L})$ & LQ $(\mu \mathrm{g} / \mathbf{m L})$ \\
\hline Palmitate & 12.99 & 40.33 \\
Linoleate & 40.40 & 134.67 \\
Oleate & 32.10 & 107.00 \\
Estearate & 41.79 & 139.30 \\
Ricinoleate & 47.13 & 157.22 \\
\hline
\end{tabular}

Table 5 Hydrolytic activities of latex of vegetable origin

\begin{tabular}{ll}
\hline Plant species & Hydrolitic activitie (U/g) \\
\hline Ficus benjamina & $6.99 \pm 0.50^{\mathrm{a}}$ \\
Manihot glaziovii Muell.Arg. & $3.40 \pm 1.67$ \\
Calotropis procera & $10.96 \pm 0.62$ \\
Jatropha curcas L. & $6.29 \pm 0.99$ \\
Ficus pumila & $3.10 \pm 0.90$ \\
Euphorbia tirucalli L. & $2.64 \pm 0.42$ \\
\hline
\end{tabular}

amean \pm standard deviation

\section{Enzyme source selection}

Transesterification reactions of castor oil were catalyzed by seven samples of commercial enzymes and with a latex sample vegetables that showed best results in testing of hidrolitic activity. The main objective was to the selection of a enzyme catalytically efficient source for obtaining biodiesel. Reactional conditions were castor oil $200 \mathrm{mg}, 50 \mathrm{mg}$ of biocatalyst, $2 \mathrm{~mL}$ of methanol, 72 hours, $28^{\circ} \mathrm{C}$ and $150 \mathrm{rpm}$ agitation. From the data of the calibration curves it was possible to quantify the methyl esters (biodiesel) obtained from the reactions to each biocatalyst. The results of these experiments are shown in Table 6.

\section{Optimization of the enzymatic transesterification reactions}

Reactional conditions for obtaining biodiesel from castor oil have been optimized using as biocatalyst enzyme Novozym 435 commercial. Due to low incomes obtained subsequent enzymatic transesterification reactions were performed with the addition of methanol in stages, to minimize the negative effect suffers enzyme activity. The parameters tested were co-solvent, molar ration alcohol/ oil, enzyme amount, $\mathrm{pH}$ and solvent for recovery of the biocatalyst.

\section{Co-solvent}

To minimize the impact of methanol on the hydration layer of enzyme organic solvents of low polarity were tested as auxiliaries, along with the addition of methanol in stages. The results obtained with the solvents tested are shown in Table 7.

\section{pH}

Enzyme activity is directly influenced by the $\mathrm{pH}$ of the medium. The optimal $\mathrm{pH}$ of lipases is usually between 6.0 and 8.0. However, there are enzymes that can act in an extremely acidic or extremely basic medium as is the case of enzymes of bacterial origin. To evaluate the effect of $\mathrm{pH}$ variation on lipase performance in chemical reactions experiments are performed in a buffered reaction medium. The enzyme activity is directly influenced by the $\mathrm{pH}$ of the medium. The $\mathrm{pH}$ optimum of lipase is typically between 6.0 and 8.0. However, there are enzymes that can perform amid extremely acidic or extremely basic, such as enzymes of bacterial origin. To evaluate the effect of $\mathrm{pH}$ variation on performance of lipase in chemical reactions are carried out experiments in buffered medium reactional. Thus, experiments using medium reactional buffered at different $\mathrm{pHs}$ were tested. The results obtained are shown in Table 8 .

\section{Molar ration alcohol/oil}

The amount of alcohol in the middle is a variable that influences the reaction yield for synthesis of biodiesel. It is known that the stoichiometric ratio alcohol: triglyceride is $3: 1$, but it is customary to use these top reasons to ensure greater reaction yield. However, in the case of enzymatic reactions an excess of alcohol can reduce the yield due to denaturation of the enzyme. Thus, it is necessary to investigate what the best alcohol/oil ratio used in reactions using lipase as catalysts. In this way, five different experiments were conducted to determine the best molar ration alcohol: oil. The results obtained are shown in Table 9 in which it noted that the best reaction yield was obtained when the molar ratio of alcohol: oil was 100: 1 (Table 9).

\section{Amount of enzyme}

To assess the effect of the variation of the amount of enzyme in relation to oil quantity, five different experiments were conducted, in which the proportions of enzyme in relation to oil were $5 \%, 10 \%$, $15 \%$ and $30 \%$. Table 10 illustrates the results obtained in this study (Table 10).

\section{Solvent for recovery of biocatalyst}

The use of immobilized enzymes presents as main advantage the possibility of re-use. However, in transesterification reactions with methanol the inactivation of the enzyme is possible even when using co-solvents and addition of alcohol in stages. In addition, the enzyme can is contaminated with traces of oil and glycerol, and for its reuse is necessary to remove any possible contaminants.

Thus, it is necessary to find out what the best treatment of recovery for the enzyme after each batch of biodiesel production. For this, the enzymes are washed with organic solvents and subsequently employed in new reactions. In the present study, the enzymes used in previous transesterification reactions were washed with three different solvents, hexane, ethanol and acetone, and after evaporation of the solvent are reused in new transesterification reactions of castor oil. The methyl esters obtained were quantified to assess the performance of each enzyme treated and the results are shown in Table 11. 
Table 6 Methyl esters (biodiesel) obtained by transesterification of castor oil with enzymatic sources in early tests

\begin{tabular}{lllllll}
\hline $\begin{array}{l}\text { Enzyme } \\
\text { source }\end{array}$ & Palmitate (\%) & Linoleate (\%) & Oleate (\%) & Estearate (\%) & Ricinoleate (\%) & Biodiesel $^{\mathrm{a}}$ (\%) \\
\hline 1 & $0.10 \pm 0.00$ & $0.25 \pm 0.04$ & $0.32 \pm 0.01$ & $0.14 \pm 0.00$ & $0.87 \pm 0.20$ & $1.68 \pm 0.49$ \\
2 & $0.07 \pm 0.00$ & - & $0.21 \pm 0.02$ & $0.12 \pm 0.00$ & $0.21 \pm 0.01$ & $0.61 \pm 0.17$ \\
3 & $0.26 \pm 0.01$ & $1.18 \pm 0.02$ & $0.59 \pm 0.02$ & $0.22 \pm 0.00$ & $3.16 \pm 0.04$ & $5.40 \pm 0.29$ \\
4 & $0.18 \pm 0.00$ & $0.72 \pm 0.01$ & $0.43 \pm 0.08$ & $0.18 \pm 0.00$ & $2.46 \pm 0.11$ & $3.97 \pm 0.45$ \\
5 & $0.40 \pm 0.01$ & $5.46 \pm 0.22$ & $1.80 \pm 0.07$ & $0.38 \pm 0.02$ & $47.29 \pm 4.23$ & $55.33 \pm 2.14$ \\
6 & $0.07 \pm 0.00$ & - & $0.20 \pm 0.01$ & $0.12 \pm 0.00$ & $0.45 \pm 0.08$ & $0.81 \pm 0.30$ \\
7 & $0.07 \pm 0.00$ & - & $0.12 \pm 0.01$ & $0.11 \pm 0.00$ & $0.29 \pm 0.01$ & $0.57 \pm 0.13$ \\
8 & $0.07 \pm 0.00$ & - & $0.20 \pm 0.01$ & - & $0.20 \pm 0.01$ & $0.47 \pm 0.12$ \\
\hline
\end{tabular}

${ }^{a}$ sum of the levels of methyl esters; ${ }^{b}$ mean \pm standard deviation ( $n=3$ ); (I) PPL; (2) Candida rugosa Lipase; (3) OS cepacea lipase Amano; (4) OS cepacea lipase Amano immobilized in diatom; (5) Novozym 435; (6) Lipozyme; (7) RM Lipozyme; (8) Latex of Calotropis procera.

Table 7 Results from the evaluation of the best co-solvent

\begin{tabular}{lllllll}
\hline $\begin{array}{l}\text { Co- } \\
\text { solvent }\end{array}$ & Palmitate (\%) & Linoleate (\%) & Oleate (\%) & Estearate (\%) & Ricinoleate (\%) & Biodiesel $^{\mathrm{a}}(\%)$ \\
\hline 1 & $1.65 \pm 0.21$ & $22.74 \pm 1.06$ & $6.62 \pm 0.29$ & $1.67 \pm 0.13$ & $39.09 \pm 1.89$ & $71.78 \pm 0.01$ \\
2 & $0.22 \pm 0.00$ & $1.71 \pm 0.05$ & $0.58 \pm 0.01$ & $0.21 \pm 0.01$ & $14.61 \pm 0.27$ & $17.33 \pm 0.00$ \\
3 & $0.08 \pm 0.01$ & $1.45 \pm 0.13$ & $0.48 \pm 0.04$ & $0.08 \pm 0.01$ & $9.16 \pm 0.34$ & $11.25 \pm 0.00$ \\
4 & $0.06 \pm 0.00$ & $1.21 \pm 0.04$ & $0.46 \pm 0.02$ & $0.09 \pm 0.00$ & $10.73 \pm 0.39$ & $12.55 \pm 0.00$ \\
5 & $0.16 \pm 0.02$ & $0.04 \pm 0.15$ & $0.78 \pm 0.35$ & $0.24 \pm 0.01$ & $0.27 \pm 1.39$ & $3.42 \pm 0.01$ \\
6 & $0.21 \pm 0.03$ & $1.18 \pm 0.31$ & $0.51 \pm 0.08$ & $0.24 \pm 0.03$ & $8.45 \pm 2.17$ & $10.59 \pm 0.01$ \\
\hline
\end{tabular}

${ }^{a}$ sum of the content of methyl esters; ${ }^{b}$ mean \pm standard deviation ( $n=3$ ); (I) Hexane; (2) Dioxane; (3) ethyl ether; (4) ethyl acetate; (5) Acetone; (6) DMSO Table 8 Results of the evaluation test $\mathrm{pH}$

\begin{tabular}{lllllll}
\hline pH & Palmitate (\%) & Linoleate (\%) & Oleate (\%) & $\begin{array}{l}\text { Estearate } \\
(\%)\end{array}$ & Ricinoleate (\%) & Biodíesel $^{\mathrm{a}}(\%)$ \\
\hline 5.2 & $1.08 \pm 0.18$ & $16.23 \pm 1.67$ & $4.76 \pm 0.41$ & $1.11 \pm 0.13$ & $46.37 \pm 1.25$ & $69.56 \pm 0.10$ \\
6.1 & $1.47 \pm 0.09$ & $20.43 \pm 0.78$ & $5.96 \pm 0.25$ & $1.51 \pm 0.09$ & $48.26 \pm 0.75$ & $77.63 \pm 0.01$ \\
7.2 & $1.40 \pm 0.10$ & $19.92 \pm 1.39$ & $6.97 \pm 1.18$ & $1.46 \pm 0.14$ & $54.89 \pm 1.50$ & $84.65 \pm 0.10$ \\
7.8 & $1.45 \pm 0.22$ & $21.19 \pm 1.42$ & $5.98 \pm 0.27$ & $1.50 \pm 0.17$ & $64.07 \pm 1.40$ & $94.20 \pm 0.01$ \\
\hline
\end{tabular}

Table 9 Results of the evaluation test best reason alcohol/oil

\begin{tabular}{lllllll}
\hline Alcohol/oil & $\begin{array}{l}\text { Palmitate } \\
(\%)^{\mathrm{b}}\end{array}$ & Linoleate (\%) & Oleate (\%) & Estearate (\%) & Ricinoleate (\%) & Biodiesel $^{\mathrm{a}}(\%)$ \\
\hline $3: 1$ & $0.10 \pm 0.02$ & $1.17 \pm 0.18$ & $0.42 \pm 0.06$ & $0.11 \pm 0.01$ & $8.65 \pm 0.98$ & $10.44 \pm 0.00$ \\
$8: 1$ & $0.22 \pm 0.02$ & $0.73 \pm 0.32$ & $0.96 \pm 0.09$ & $0.25 \pm 0.01$ & $33.13 \pm 0.84$ & $37.28 \pm 0.01$ \\
$10: 1$ & $0.28 \pm 0.03$ & $5.22 \pm 0.16$ & $1.40 \pm 0.08$ & $0.28 \pm 0.01$ & $41.32 \pm 1.06$ & $48.49 \pm 0.01$ \\
$100: 1$ & $1.00 \pm 0.22$ & $17.74 \pm 2.73$ & $4.75 \pm 0.95$ & $1.64 \pm 1.15$ & $58.17 \pm 0.39$ & $83.31 \pm 0.01$ \\
$240: 1$ & $1.65 \pm 0.21$ & $22.74 \pm 1.06$ & $6.62 \pm 0.30$ & $1.67 \pm 0.13$ & $39.09 \pm 1.88$ & $71.78 \pm 0.00$ \\
\hline
\end{tabular}

asum of the levels of methyl esters; bmean \pm standard deviation $(n=3)$

Table I 0 Results of the evaluation test of the best amount of enzyme

\begin{tabular}{|c|c|c|c|c|c|c|}
\hline $\begin{array}{l}\% \text { Enzyme (g/l00 } \\
\text { g of oil) }\end{array}$ & Palmitate (\%) & Linoleate (\%) & Oleate (\%) & $\begin{array}{l}\text { Estearate } \\
(\%)\end{array}$ & Ricinoleate (\%) & Biodíesel $^{\text {a }}(\%)$ \\
\hline 5 & $0.04 \pm 0.00$ & $0.08 \pm 0.03$ & $0.13 \pm 0.02$ & $0.07 \pm 0.00$ & $3.00 \pm 0.25$ & $3.31 \pm 0.00$ \\
\hline 10 & $3.09 \pm 0.19$ & $3.11 \pm 0.11$ & $9.62 \pm 1.15$ & $3.00 \pm 0.18$ & $50.38 \pm 1.59$ & $69.22 \pm 0.01$ \\
\hline 15 & $0.89 \pm 0.08$ & $15.96 \pm 0.93$ & $4.69 \pm 0.26$ & $0.95 \pm 0.06$ & $64.85 \pm 2.84$ & $87.36 \pm 0.01$ \\
\hline 30 & $0.65 \pm 0.05$ & $12.95 \pm 0.30$ & $3.82 \pm 0.08$ & $0.75 \pm 0.02$ & $80.66 \pm 4.31$ & $98.84 \pm 0.01$ \\
\hline
\end{tabular}


Table I I Results of tests to assess the best solvent for enzyme recovery

\begin{tabular}{llllllr}
\hline Solvent & Palmitate (\%) & Linoleate (\%) & Oleate (\%) & Estearate (\%) & Ricinoleate (\%) & Biodiesel (\%) \\
\hline Hexane & $1.91 \pm 0.20$ & $20.45 \pm 0.80$ & $6.06 \pm 0.36$ & $1.86 \pm 0.07$ & $25.86 \pm 1.38$ & $56.16 \pm 0.01$ \\
Ethanol & $1.51 \pm 0.08$ & $17.82 \pm 0.92$ & $5.32 \pm 0.36$ & $1.49 \pm 0.11$ & $26.20 \pm 3.15$ & $52.39 \pm 0.01$ \\
Acetone & $1.60 \pm 0.18$ & $21.32 \pm 1.47$ & $5.88 \pm 0.45$ & $1.48 \pm 0.11$ & $58.25 \pm 1.40$ & $88.54 \pm 0.01$ \\
\hline
\end{tabular}

\section{Discussion}

The results showed that the validation of the analytical method occurred properly. According to the values of R (Table 1), we can observe that the response of the detector is linear the concentration of methyl esters in the concentration range studied. For all methyl esters near $100 \%$ recoveries were obtained (Table 2), indicating good accuracy of the method and a poor influence of the sample (oil) matrix. The data (Table 3) showed a good precision of the results, indicating that analyzes on different days will slightly alter the response of the equipment. The limits (LD and LQ) obtained were high (Table 4), however, it must be noted that the solution was diluted 21 times indicating that the actual limits are much lower than those calculated by this method.

The study showed low hydrolytic activity of the tested latex (Table 5). The greatest value of activity found for species Calotropis procera. As a result more expressive activity was obtained for this species, it was used in reactions with castor oil in order to assess its performance against the transesterification reactions, because positive values of hydrolytic activity is an indication of the presence of lipase. In this initial test, it was possible to verify low conversion in the methyl transesterification reaction of castor oil by the enzyme sources tested, except for enzyme 5, Novozyme 435 (CAL B), with training of $55.33 \%$ biodiesel (Table 6). However, data from the literature reported results well above when it comes to Novozyme $435(>90) .{ }^{19-21}$ Even when the quantification is performed compared to methyl ricinolato, which is the main constituent of castor oil, the results remain low. The low yield reaction, even for commercial enzymes, can be justified by the high amount of methanol used, inserted in the middle of a single time, as this decreases the hydration layer of the inner structure of the enzyme, disabling it or reducing its activity. To work around this limitation, some studies have been conducted with the addition of alcohol in stages. As an example can be cited the study by Salum et al. (2010), ${ }^{22}$ who reported better performance of lipase from type B. cepacia, when alcohol was added in steps in transesterification reactions of soya-bean oil. The results obtained were of $77 \%$ when ethanol was added in a single step and $92 \%$ when added to the medium reactional in three steps. On the basis of this information, the following experiments were carried out with the addition of methanol on steps to reduce the impact of alcohol on the enzyme activity. Also, we decided to work only with the enzyme that presented better result in initial testing, the Novozym 435.

The study to optimize the conditions of the transesterification enzymatic reaction was carried out with Novozym 435, the most efficient enzyme source among those tested. Data from the literature report that nonpolar solvents can protect the hydration layer through interaction with the hydrophobic portion of the enzyme. In this way, the hydrophobic solvents form a protective film preventing the interaction of hydrophilic solvents with the enzyme, preventing hydration layer their dehydration and making it more stable and active. ${ }^{22}$ The results shown (Table 7 ) that hexane was the best cosolvent for the transesterification reaction of castor oil using the enzyme Novozym 435. Already the acetone, with higher capacity dryer, which led to lower yield. As mentioned earlier, high polarity solvents can cause inactivation of lipase. This explains the low yields obtained in experiments with single addition of methanol and acetone as co-solvent. Based on this information, it was expected that the best results were obtained with nonpolar solvents and gradual addition of alcohol. Some studies reinforce the results, reporting good yields when using reactional this solvent on reactions of esterification and transesterification catalyzed by lipase. ${ }^{23,24}$ Based on the $\mathrm{pH}$ assessment of the medium, it appears that the enzyme performed better when used at pH 7.8 (Table 8). Such a result is in accordance with data from the literature that report to this enzyme optimum values of $\mathrm{pH}$ around 7 , when using the phosphate buffer solution. In addition, one must take into consideration that the buffer solutions are liquids containing ions that can activate the enzyme. Thus, taking into consideration this fact we can see that for bigger $\mathrm{pH}$ values the enzyme showed better results, this may be due to increased concentration of ions in solution that may be contributing to the improved performance of lipase. Such data can be verified in the literature reports that some cations and anions influencing the behavior of some enzymes activating or inactivating them. In this specific case the ions present in the medium reactional are sodium cations and phosphate anions, both are reported in the literature as ions which activate enzymes. However, no data were found to explain how these ions may influence the enzyme activity.

Another important variable evaluated was the alcohol/oil molar ratio. Analyzing the data in the Table 9 immediately, these may seem inconsistent with what was previously discussed on the influence of polar solvents. So, it was expected that reasons molars of alcohol/oil very high oil would result in low yield. However, what was observed a high yield for the reasons 100:1 and 240:1. This can be justified by the additions of methanol in stages, that minimize the harm done by alcohol on the enzyme..$^{24,25}$ Another aspect to be reported is that the methanol used wasn't anhydrous, i.e. containing small amounts of water can form a layer of hydration in the enzyme, protecting the denaturation by solvent.?

The study of the best amount of enzyme in the transesterification reaction showed that, with the exception of the experiment which used $5 \%(\mathrm{w} / \mathrm{w})$ of enzyme, all the results obtained were satisfactory (Table 10). In all cases the yield of biodiesel was exceeding $50 \%$. Generally, the reaction yield increased with the increase of the quantity of catalyst. The type of solvent used to wash the enzyme, for the purpose of reuse, was evaluated. On the basis of the yields (Table 11), it turns out that the best solvent for recovery of the enzyme was acetone. As previously reported, the very polar solvents can remove the hydration 
layer of enzymes by decreasing their activity. On the other hand, the use of very nonpolar solvents on enzyme wash may not be efficient due to the presence of polar contaminants such as glycerol. Therefore, the best performance was observed when reused the enzyme washed with an solvent of intermediate polarity, acetone. Generally speaking, the results obtained in the reuse of enzymes, washed with different solvents, were consistent.

\section{Conclusion}

The study showed that among the enzymatic sources tested commercial enzymes were more effective, especially Novozym 435. However, the plant sources (latex) showed activity compatible with some commercial enzymes. Analytical method validation showed a satisfactory behavior for linearity, precision and accuracy, however the high detection and quantification limits possibly due to dilution with the solution of internal standard. The experimental methodology could be improved when used a co-solvent apolar, a medium with $\mathrm{pH}$ slightly alkaline, high alcohol/oil ratio and a relationship between the biocatalyst and oil of 3/101, generating biodiesel yield close to $99 \%$. Since the recovery of the enzyme for more cycles was more effective when was washed with a solvent of moderate polarity. Therefore the present study allowed the development of an efficient method of chemical and analytical point of view to obtain biodiesel from castor oil using a commercial enzyme as a catalyst which has the advantage of being reused for several cycles.

\section{Acknowledgments}

The authors thank FUNCAP (Ceara foundation to support scientific and technological development) for the financial assistance, CAPES (Coordination for the Improvement of Higher Education Personnel) and IFCE (Federal Institute of Ceara) for the design of scholarships and UFC (Federal University of Ceara) for the provision of laboratory infrastructure.

\section{Conflicts of interest}

The author declares that there are no conflicts of interest.

\section{References}

1. Lobo IP, Ferreira SLC. Biodiesel:Parâmetros de Qualidade e Métodos Analíticos. Quim Nova. 2009;32(6):1596-1608.

2. Srivathsan VR, Srinivasan LN, Karuppan M. An overview of enzymatic production of biodiesel. Bioresour Technol. 2008;99(10):3975-3981.

3. Kaieda M, Samukawa T, Matsumoto T, et al. Biodiesel fuel production from plant oil catalyzed by Rhizopus or yzae lipase in a water containing system without an organic solvent. J Biosci Bioeng. 1999;88:627-631.

4. Fukuda H, Kondo A, Noda H. Biodiesel fuel production by transesterification of oils. J Biosci Bio eng. 2001;92:405-416.

5. Gazzoni DL. Historia e Biodiesel. 2012;

6. Oliveira FCC, Suarez PAZ, Santos WLP. Biodiesel:Possibilidades Desafios. QNEsc. 2008;28:3-8.

7. Saad EB. Corn Oil Ethanolysis Using Alkaline and Enzymatic Catalysts. Dissertation (master's), Postgraduate Course in Chemistry, Concentration Area: Organic Chemistry, Federal University of Paraná, 2005.

8. Hamsaveni R, Prapulla SG, Divakar S. Response surface methodological approach for the synthesis of isobutyl isobutyrate. Proc Biochem. 2001;36:1103-1109.
9. Vicente DG, Coteron A, Martinez M, et al. Application of the factor design of experiments and response surface methodology to optimize biodiesel production. Ind Crops Prod. 1998;8:29-35.

10. Kaieda M, Samukawa T, Kondo A, et al. Effect of methanol and water contents on production of biodiesel fuel from plant oil catalyzed by various lipases in a solvent-free system. J Biosci Bioeng. 2001;91:12-15.

11. Embrapa. Cadeia Produtiva - Óleo de Mamona e Biodiesel. 2012;

12. Nogueira NS. Delphi and SWOT Analysis of Biodiesel Production Raw Materials: Soy, Castor and Microalgae. Dissertation (Master's), Graduate Program in Chemical and Biochemical Process Technology, Federal University of Rio de Janeiro, 2010.

13. Pina M, Seveno LS, Beltrão NEM, et al. De Nouvelles Voies de Valorisation pour Redynamiser la Filière Ricin au Brésil. Cah Agric. 2005;14(1):169-171.

14. Moreira ABR. Lipase Source Selection for Biodiesel Synthesis by Enzymatic Transesterification of Palm Oil with Ethanol. Dissertation (master's degree), Lorena School of Engineering. Brazil: University of São Paulo; 2007.

15. Fregonezi-Nery MM, Bacarat MM, Casagrande R, et al. Validation of methods for determining fluoxetine in capsules. Quim Nova. 2008;31(7):1665-1669

16. Barros M, Fleuri L F, Macedo GA. Seed Lipases: Sources, Applications and Properties- A Review. Braz J Chem Eng. 2010; 27 (1): 15-29.

17. Palocci C, Soro S, Cernia E. et al. Lipolytic isoenzymes from Euphorbia latex. Plant Sci. 2003;165(3):577-582.

18. Paques FW, Macedo GA. Vegetable Latex Lipase: Properties and Industrial Applications-Review. Quim Nova. 2006;29(1):93-99.

19. Kiakalaieh AT, Amim NAA, Mazaheri H. A Review on Novel Processes of Biodiesel, from Waste Cooking Oil. J Appl Energ. 2013;104:683-710.

20. Haigh KF, Saha B, Vladisavljevi GT, et al. Kinetics of the Pre-Treatment of Used Cooking Oil Using Novozyme 435 for Biodiesel Production. $J$ Procedia Eng. 2012;42:1106-1113.

21. Samukawa T, Kaieda M, Matsumoto T, et al. Pretreatment of immobilized Candida antarctica lipase for biodiesel fuel production from plant oil. $J$ Biosc Bioeng. 2000;90(2):180-118.

22. Salum TFC, Villeneuve P, Barea B, et al. Synthesis of biodiesel in column fixed-bed bioreactor using the fermented solid produced by Burkholderia cepacia. Process Biochem. 2010;45(8):1348-1354.

23. PWC hawk. Production of biodiesel in supercritical medium. Thesis (Doctorate), Sciences in Chemical Engineering, Luiz Coimbra Institute for Postgraduate Studies and Engineering Research (COOPPE). Brazil: Federal University of Rio de Janeiro; 2011.

24. Rampim MA. Synthesis of ethyl esters obtained from castor and soybean oils using the immobilized lipase of Thermomyces Lanugiosus (Lipozyme $T L$ IM). Thesis (Master's degree). Brazil: Faculty of Philosophy, Sciences and Letters of Ribeirão Preto, Department of Chemistry, São Paulo; 2007

25. Souza LTA. Enzymatic Synthesis of Biodiesel from Jatropha curcas along the Ethyl Route. Dissertation (Master's), Lorena School of Engineering. Brazil: University of São Paulo, Graduate Program in Chemical Engineering, concentration area: Catalytic and Biocatalytic Processes. Lorena; 2010 